\title{
Salmonella Serotype Typhimurium
}

National Cancer Institute

\section{Source}

National Cancer Institute. Salmonella Serotype Typhimurium. NCI Thesaurus. Code C86927.

Any bacterial organism that can be assigned to the genus Salmonella with serotype Typhimurium. 